\title{
Myelinated Nerve Fiber
}

National Cancer Institute

\section{Source}

National Cancer Institute. Myelinated Nerve Fiber. NCI Thesaurus. Code C12627.

A nerve axon that is surrounded by a layer of myelin. 